\title{
ПОНЯТТЯ, ЗНАЧЕННЯ \\ ТА СКЛАДНИКИ ПРОЦЕСУАЛЬНОЇ ФОРМИ ЦИВІЛЬНОГО СУДОЧИНСТВА
}

Перунова О. М., Леонтьєва Л. В.

\section{ВСТУП}

Завданням цивільного судочинства є справедливий та своєчасний розгляд і вирішення цивільних справ з метою ефективного захисту порушених, невизнаних або оспорюваних прав, свобод чи інтересів фізичних осіб, прав та інтересів юридичних осіб, інтересів держави ${ }^{1}$.

Стаття 2 ЦПК 2018 року визначає основні завдання, які стоять перед судом, шляхом розгляду і вирішення цивільних справ у разі додержання процесуальної форми та правильного застосування належних норм цивільного права. Логічним, аргументованим, підсумковим результатом розгляду цивільної справи $\epsilon$ винесення судового рішення, а якщо необхідно перегляд справи в апеляційному та касаційному оскарженні.

Одним $з$ головних чинників правової діяльності держави $є$ взаємозв'язок моралі і права, їх сумісне зближення, яке знаходить своє яскраве відображення у цивільному судочинстві, а також у розвитку і вдосконаленні цивільно-процесуальної форми.

Так, Р.В. Тертишніков зазначає, що побутове, життєве пізнання здійснюється шляхом вільного вибору його методів, засобів та ін., а саме судове пізнання має проходити у рамках проиесуальної форми².

Безперечно, цивільне судочинство являє собою дуже складну ланку, яка містить велику кількість складників, від яких залежить не тільки прийняття цивільної справи до розгляду, а й вирішення ï бажано законно й обгрунтовано для всіх учасників цивільного процесу.

В українській юридичній літературі до цього часу не сформульовано загального чіткого поняття «процесуальна форма», іiї складників цивільного судочинства, хоча багато авторів приділяли увагу саме їй.

Серед таких юристів-теоретиків - В.М. Горшеньов, П.С. Недбайло, В.М. Шпілєв, М.А. Якуб та ін.

1 Цивільний процесуальний кодекс України: станом на 2 лютого 2018 року. Харків : Право. 2018. С. 8.

2 Тертишніков Р.В. Доказування і докази в судочинстві України : науково-практичний посібник. Харків : Видавництво «ФІНН», 2009. С. 13. 
Так, В.М. Горшеньов під процесуальною формою розуміє сукупність однорідних процесуальних вимог, які висуваються до дій учасників процесу і спрямовані на досягнення якогось певного результатуз

П.Є. Недбайло зазначає, що процесуальна форма - це здійснення прав та обов'язків, включає діяльність їх носіїв і інших суб'єктів права з опосередкуванням процесу реалізації цих прав і обов'язків у певних документах ${ }^{4}$.

Певні думки стосовно поняття «процесуальна форма» висвітлювали представники науки кримінального процесу, серед яких B.M. Шпілєв, який вважав, що внутрішня правова форма кримінального процесу (процесуальні відносини) і зовнішня процесуальна форма (форма процесуальної процедури) тісно зв'язані між собою і утворюють щось єдине

М.А. Якуб розглядає процесуальну форму як сукупність встановлених процесуальним законом умов, у яких здійснюється як діяльність загалом, так і кожна окрема процесуальна дія (чи комплекс таких дій) і ухвалюється кожне рішення у справі, яким зазначається зв'язок і послідовність запроваджуваних дій і прийнятих рішень. Процесуальна форма (процесуальний порядок) утворює детально врегульоване стійне юридичне визначення, суворо обов'язковий стабільний правовий режим діловодства 6 .

Отже, процесуальна форма цілком залежить від наповненості iii змісту та певних елементів, без яких неможливо представити сам цивільний процес. Процесуальна форма являє собою певну частину процесуальних правил, встановлених процесуальним законодавством. Нормативне регулювання процесуальної форми здійснюється згідно 3 нормами ЦПК України. Правила, які не встановлені законом, не можуть регулювати порядок діяльності осіб, які беруть участь у судовому розгляді.

\footnotetext{
3 Горшенёв В.М. Способы и организационные формы правового регулирования в социалистическом обществе. Москва : Юрид. лит., 1972. С. 190-191.

4 Юридическая процессуальная форма: теория и практика / Под общ. ред. Гл.-кор. АН КССР Недбайло П.Е. и д-ра юрид. наук Поршнева В.М. Москва : Юрид. лит., 1976. C. 111-113.

5 Шпилев В.Н. Содержание и форма уголовного судопроизводства. Минск : Изд-во БГУ, 1974. С. 102.

6 Якуб М.А. Процессуальная форма в советском уголовном судопроизводстве. Москва : Юрид. лит., 1981. С. 8.
} 


\section{1. Процесуальна форма цивільного судочинства}

Перш за все процесуальна форма цивільного судочинства являє собою сукупність певних правил, які визначають зміст поведінки суду і учасників процесу, порядок та послідовність такої поведінки і здійснюється у рамках цивільних процесуальних правовідносин; визначення місця і строків реалізації процесуальних прав та обов'язків; визначення доказової бази; визначення логічності та послідовності процесуальних дій; фіксацію процесуальних дій та руху цивільного процесу. Процесуальна поведінка суду та учасників процесу суворо закладена у ЦПК України, і якщо дії здійснюються без певної нормативної послідовності вони стають безпредметними. Тому суд $є$ тим спеціальним, виключним учасником цивільного процесу, який має регулювати дотримання процесуальних норм цивільного судочинства.

Судова влада - це система утворених відповідно до закону органів, які наділені виключними владними повноваженнями щодо розгляду юридично значущих справ із застосуванням спеціальної, визначеної законом, процесуальної форми, яка містить гарантії законності і справедливості рішень, що приймаються .

Таким чином, суд $є$ гарантом реалізації процесуальної форми цивільного законодавства та винесення законного та обгрунтованого судового рішення. Тим паче, що Конституція України зазначає, що кожному гарантується право на оскарження в суді рішень, дій чи бездіяльності органів державної влади, органів місцевого самоврядування, посадових і службових осіб (ст. 55), а юрисдикція судів поширюється на всі правовідносини, які виникають у державі (ст. 124).

Не секрет, що діяльність суду базується на стадійності цивільного процесу. Кожна стадія характеризується своїм специфічним змістом, колом суб'єктів процесуальної діяльності, особливим процесуальним оформленням. I тут треба підкреслити велике значення оформлення процесуальних дій судом і учасниками цивільного процесу.

Отже, процесуальна форма цивільного судочинства являє собою поступовий рух і розвиток по стадіях процесу. У науці цивільного процесуального права виділяють такі ознаки стадії цивільного судочинства, як: 1) наявність часових і просторових меж; 2) наявність самостійної мети і завдань; 3) існування комплексу цивільних процесуальних відносин; 4) відображення результатів у спеціальних процесуальних

\footnotetext{
7 Організація роботи суду : навчальний посібник для студентів юридичних спеціальностей вищих навчальних закладів / I.Є. Марочкін, Л.М. Москвич, О.М. Овчаренко та ін. ; за заг. ред. І.С. Марочкіна. Харків : Право, 2012. С. 7.
} 
актах; 5) особлива процедура виникнення і розвитку; 6) наявність особливостей процесуального становища суб'єктів процесу; 7) специфіка реалізації принципів цивільного процесу.

Стадію цивільного судочинства можна визначити як частину цивільного судочинства, процесуальної форми, в межах якої вирішуються самостійні процесуальні завдання, які характеризують особливості процесуального регулювання порядку розгляду і вирішення цивільних справ, перегляду судових рішень, вирішення окремих процесуальних питань, що постають перед судом у межах цивільної процесуальної форми.

Вважаємо, що співвідношення поняття «цивільне судочинства» та поняття «цивільна процесуальна форма» являє собою певну аналогію і хронологію поступових дій у цивільному процесі, причому зафіксованому у ЦПК України, і тому ці поняття є ідентичними з точки зору юридичного підходу.

Фіксація результатів процесуальної поведінки - це так звана зовнішня сторона процесуальної форми, основу якої становлять процесуальні засоби, за допомогою яких фіксується порядок і результати процесуальної діяльності учасників цивільного судочинства. Такими засобами реалізації оформлення стадій цивільного процесу (процесуальної форми) є документація та фіксування технічними засобами, серед яких, наприклад, можна зазначити протокол судового засідання.

Документування - це утворення документа з використанням різних методів, способів і засобів фіксування інформації на матеріальному носієві ${ }^{8}$.

Документування є багатоаспектним, структурно розведеним, воно торкається різних сторін самого документа і комунікаційної діяльності - явищ не менш складних і багатогранних. 3 цієї причини сам термін важко піддається тлумаченню, тим паче, чіткому поняттю, оскільки значення кожного документа та його зміст несе в собі різну форму інформації, і сам процес фіксації кожного з документів, особливо у юридичних науках, $є$ різним.

На наш погляд, це загальне поняття документування, яке не дає спеціальної характеристики процесуального документування у цивільному судочинстві. У науці цивільного процесу вважаємо доцільним використати поняття «процесуальне документування», під яким слід вважати здійснюваний судом, учасниками судового

8 Кушнаренко Н.Н. Документоведение : учебник. 8-е изд., стер. Киев: Знання, 2008. C. 67. 
процесу, заснований на нормах цивільно-процесуального права комплекс взаємозалежних дій і рішень, спрямованих на достовірне відображення у цивільно-процесуальних актах порядку і результатів як окремих процесуальних дій і рішень, так і всього ходу і результатів вирішення цивільної справи.

Таким, чином, поняття «процесуальне документування» дає змогу розглядати його (документування) як особливу, загальну категорію, яка спрямована на законне та обгрунтоване вирішення справи і яка невідривно пов'язана із процесуальною формою цивільного судочинства.

Так, О.Б. Олійник у своїй праці зазначає, що документ має відповідати конкретним вимогам: видається повноважним органом або особою відповідно до їхньої компетенції; не мусить суперечити чинному законодавству і директивним указівкам керівних органів; бути достовірним і відповідати завданням конкретного керівництва, тобто базуватися на фактах і містити конкретні пропозиції або вказівки; відповідати своєму призначенню й укладатися за встановленою формою; має бути бездоганно відредагований і оформлений 9

Це так, але у цивільному судочинстві документ перш за все являє собою процесуальний акт-документ, який оформлений певним чином, згідно 3 кожною стадією цивільного процесу, він характеризується своїм специфічним змістом, колом суб'єктів процесуальної діяльності, особливим процесуальним оформленням, яке закріплене у законодавстві відповідно до свого історичного розвитку і мети, відображається у процесуальній формі і змісті кожного 3 процесуальних актів-документів.

На сучасному етапі розвитку цивільного діловодства процесуальна форма та зміст оформлення процесуальних актів-документів здійснюється за допомогою технічних засобів, прийомів.

Відповідно до п. 7 ч. 3 ст. 129 Конституції України, пунктів 10, 11 ст. 6 та ст. 197 Цивільного процесуального кодексу України, ст. 41 Кодексу адміністративного судочинства України, ст. 4 Господарського процесуального кодексу України, п. 4 ст. 9, п. 14 ст. 126 Закону України «Про судоустрій в Україні» реалізація принципу гласності судочинства забезпечується за допомогою повного фіксування судового процесу технічними засобами.

Згідно зі ст. 129 Конституції України та ст. 6 ЦПК України фіксування судового процесу технічними засобами є однією з гарантій гласності судового процесу.

9 Олійник О.Б. Судова документація : навчальний посібник. Київ : Алерта, 2007. С. 7. 
Гласність правосуддя забезпечує його виховні та профілактичні функції; сприяє зниженню суб'єктивізму суддів і дає змогу всім бажаючим переконатися в дотриманні встановлених цивільним процесуальним законодавством правових процедур розгляду цивільної справи ${ }^{10}$.

Отже, фіксування судового процесу у процесуально-правовому аспекті означає відбиття, закріплення юридично значущих дій суду, інших учасників судового процесу у відповідних процесуально-документальних формах для забезпечення їх вірогідності з точки зору об'єктивності засобів фіксації судового процесу та визначення процесуальних наслідків цих дій у разі розгляду справи по суті на різних стадіях судового процесу.

Таким чином, фіксація цивільного процесу є обов'язковою у разі документального оформлення процесуальних актів-документів, які фіксують процесуальні дії суду, сторін та інших учасників судового процесу, а також обставини, юридичні факти під час розгляду цивільної справи.

Сучасний етап розвитку документування суду вимагає єдності між процесуальною формою акта-документа в його класичному письмовому прояві та фіксуванні цього ж акта-документа технічними засобами, які мають певні переваги.

На наш погляд, фіксування цивільного процесу технічними засобами має певну перевагу перед класичним письмовим оформленням актів-документів, а саме:

- завдяки технічним засобам фіксації підлягають усі факти процесуальної поведінки суду та учасників процесу, навіть і та інформація, яка не має процесуального значення;

- фіксація судового засідання запобігає тим чи іншим перекручуванням ходу судового засідання або фальсифікації з боку учасників судового процесу, що не виключається у разі протокольної фіксації судового засідання, та підвищує певною мірою довіру до суду;

- у разі перегляду цивільної справи у вищестоящому суді технічний запис процесу виступає як доказ для розгляду справи і є для вищестоящого суду тією якістю, достовірністю та повнотою для вивчення та перегляду цієї справи;

- фіксація судового засідання сприяє скорішому наданню фізичним та юридичним особам інформації про стан розгляду справи, у яких вони беруть участь.

10 Васильєв С.В. Цивільний процес : навчальний посібник. Харків : Еспада, 2014. С. 45. 
Слід зазначити, що якість бездоганного фіксування цивільного процесу потребує досконалого програмного й технічного забезпечення у всіх сучасних судах. Засоби фіксування судового засідання мають відповідати надійності та простоті використання персоналом суду і забезпечувати легітимність звукозапису.

Так, відповідно до ч. 2 ст. 197 ЦПК України технічне фіксування судового засідання здійснює секретар або за розпорядженням головуючого інший працівник апарату суду (у будь-якому разі це мають бути працівники, які пройшли відповідне навчання). Одночасно з проведенням фіксування технічними засобами секретарем судового засідання ведеться журнал судового засідання відповідного технічного зразка.

Таким чином, сьогодення фіксації цивільного судочинства пропонує використовувати як класичну форму оформлення процесуальних актів-документів, так і нову - технічну фіксацію судового процесу.

Отже, всі якості класичного документування цивільних процесуальних актів-документів, а саме достовірність і об 'єктивність, точність, якість повноти інформації, лаконічність і доступність, мають злитися з технічним засобом фіксування цивільного судочинства, і одне не мусить суперечити іншому.

Безперечно, сучасне фіксування судового процесу та і майбутня автоматизація судових справ вимагають від працівників судової системи, учасників судового процесу, самого суду певної підготовки і класифікації, невелика неточність, недотримання у викладенні інформації, юридичних фактів, доказів буде вести до скасування судового рішення чи його перегляду.

Тому велике значення нині має модернізація української інформаційно-комунікаційної системи судів за напрямом уведення повноцінної моделі електронного суду, з певними кваліфікованими спеціалістами з обслуговування цієї судової системи.

Запровадження електронного суду є результатом фактичного використання новітніх технологій та їх законодавчого закріплення в галузі судочинства ${ }^{11}$.

Серед ключових особливостей нині слід виділити: електронне заповнення позовних документів; консультація в електронній формі стосовно інформації та документів, що використовуються в процесі судочинства; проведення судових засідань в електронній формі; електронні запити та надання електронних копій; можливість

\footnotetext{
11 Барікова А.А. Електронна держава: нова ефективність урядування : монографія. Київ : Юрінком Інтер, 2016. С. 58.
} 
використання електронної адреси, на яку користувачі системи можуть отримувати інформацію з канцелярії суду або від юристів ${ }^{12}$.

Отже, процесуальна форма і зміст цивільного судочинства нині будуються і залежать від великої кількості усних, письмових актів-документів, оформлених технічним способом. Оформлення і фіксування судового цивільного процесу означає відбиття, закріплення юридично значущих дій суду, учасників судового розгляду на різних стадіях цивільного процесу у відповідних процесуально-документальних формах з притаманним лише їм специфічним змістом.

Слід зазначити, що велика кількість документів, особливо інформаційних, не мають фіксованої процесуальної форми і змісту. Вважаємо, що цей недолік у майбутньому буде виправлений на законодавчому рівні.

Таким чином, фіксування цивільного судочинства технічними засобами, безумовно, сприяє розвитку новітніх технологій у галузі судоустрою і підвищує якість правосуддя. Ці переваги є і вони гарантують доступ до правосуддя, швидкість розгляду справ судами, мають сприяти підвищенню якості судових рішень, участі та контролю сторін за розглядом справи та економії судових витрат, посилить змагальність та публічність судових процесів. Усе це можливо, але за умови правової технічної освіти населення та певних спеціалістів з обслуговування цієї інформаційної судової системи і не лише в залі судового засідання, а і за іiі межами.

Впевнені, що інформаційні технологій, використання їх у суді будуть тим фундаментом, що викличе теоретичні зміні у понятті процесуальної форми цивільного судового процесу, а можливо, і змінять їі зміст.

Таким чином, без документування, фіксації цивільного процесу технічними носіями неможливе здійснення і реалізація ознайомлення учасників цивільної справи з матеріалами ходу справи, визначення та пред’явлення доказів у справі. Реалізація цього фіксування забезпечує для процесуальної форми ії особливий зміст і юридичну силу реалізації норм цивільного судочинства, яке здійснюється згідно із зазначеними у цивільному законодавстві правилами і нормами.

12 Кушакова-Костицька Н.В. Електронне правосуддя: українські реалії та зарубіжний досвід. Юридичний часопис Національної академії внутрішніх справ. 2013. № 2(4). С. 5-15. 


\section{2. Документування. Юридична техніка в цивільному судочинстві}

Завданнями цивільного судочинства є справедливий та неупереджений і своєчасний розгляд та вирішення цивільних справ із метою захисту порушених, невизнаних або оспорюваних прав, свобод чи інтересів фізичних осіб, прав та інтересів юридичних осіб, інтересів держави ${ }^{13}$.

Сучасність процесуальної діяльності цивільного суду пов'язана перш за все із системою правових норм, які закріплюють вимоги 3 використання певних процесуальних способів і прийомів, застосування та складання процесуальних актів-документів, які притаманні певній стадії цивільного процесу, механізму вирішення з конкретної цивільної справи, яка приймається судом до розгляду.

Тобто під час вирішення цивільної справи суд керується певними правовими, процесуальними прийомами, механізмом стадійного руху цивільної справи, яка пов'язана 3 процесуальними діями суб'єктів судового розгляду та їх документальним оформленням, що, безперечно, утворює сам цивільний процес (цивільне судочинство) як встановлений законом порядок розгляду і вирішення цивільної справи.

Документування, технічне чи письмове, у суді має на меті закріплення всіх дій, які виконані в судовому засіданні саме в усній формі, бо процесуальна усність без іiі фіксування не має можливості в такій формі накопичуватись та зберігатись упродовж тривалого часу. Це дає змогу забезпечити контроль вищим судом за додержанням реалізації всієї процесуальної форми та процесуальних дій судів нижчого рівня у ході розгляду ними цивільних справ.

Також не слід забувати, що діяльність суду базується, зокрема, на роботі з процесуальними документами (актами), суди самі укладають різноманітні документи, які теж набувають письмової процесуальної форми і змісту і $є$ нормативно закріпленими у ЦПК України.

Вважаємо, що процесуальна форма, іiі зміст залежать від використання учасниками судового розгляду юридичних фактів (процесуальних доказів), які, безперечно, являють собою різну форму і зміст інформації, а також процесуальне різноманіття видових характеристик (документи, технічні записи, показання свідків тощо).

Суттєвою ознакою цивільної процесуальної форми є аргументація та викладення юридичних фактів у справі.

13 Онищук I.I. Техніка юридичного письма в нормативно-правових актах : монографія. Івано-Франківськ : Лабораторія академічних досліджень правового регулювання та юридичної техніки, 2014. С. 95. 
Практична логіка юридичної аргументації узгоджена зі спеціальними гносеологічними принципами практики юридичного пізнання. Зокрема, це принцип всесторонності, повноти та об'єктивності. Всесторонність дослідження означає, що для пізнання предмета доказування та обставин, що мають значення для справи, були проведені всі необхідні юридико- пізнавальні процедури, перевірені всі можливі версії. Повнота означає досягнення достатності доказів у сукупності, що представлені для підтвердження обставин справи. При цьому повнота щодо різних юридичних справ може бути різною, але головне, щоб вона забезпечила необхідну сукупність доказів для прийняття судового рішення. Об'єктивність означає безпристрасне, незаінтересоване дослідження будь-яких обставин ${ }^{14}$.

Таким чином, вважаємо, що доказування являє собою складну розумову діяльність суду та учасників цивільного процесу, яка є певним гарантом у передбаченому законом порядку встановлення чи відсутності юридично значимих фактів для ухвалення законного та обгрунтованого судового рішення.

Отже, доказування для процесуальної форми цивільного судочинства являють певну юридичну цінність і автоматично стають процесуальними, оскільки якщо вони прийняті судом і зазначені у справі, то, безперечно, впливатимуть на процесуальну форму і зміст цивільного процесу, на хід конкретної справі.

Процесуальні докази сприймаються учасниками цивільного процесу як певна матеріальна база юридичних фактів, правова інформація, на основі якої суд виносить бажано законне й обгрунтоване рішення.

Також вважаємо, що процесуальна форма, ії зміст впливають на процесуальні відносини між учасниками цивільного процесу. Нормативна системність цивільної процесуальної форми полягає у визначенні в цивільному процесуальному Кодексі: переліку учасників цивільного судочинства; процесуального становища кожного учасника процесу, послідовності вчинення кожним учасником процесуальних дій, взаємозв'язку і залежності процесуальних дій учасників процесу.

Під час розгляду структури процесуальної форми цивільного судочинства не слід забувати про принципи цивільного процесуального права. Науковцями запропоновано різноманітні критерії принципів, а саме: 1) за джерелом закріплення (конституційні принципи

14 Юридична аргументація. Логічні дослідження : монографія / О.М. Юркевич, В.Д. Титов, С.В. Куцепал та ін. ; за заг. ред.. О.М. Юркевич. 2-ге вид, переробл. та допов. Харків : Право, 2015. С. 127. 
цивільного процесуального права і принципи, закріплені галузевим законодавством); 2) за сферою поширення (загальноправові принципи, міжгалузеві, галузеві принципи, принципи правових інститутів); 3) за об'єктом регулювання (організаційно-функціональні принципи, функціональні принципи).

Основними принципами, які впливають на процесуальну форму цивільного судочинства, $\epsilon$ функціональні принципи: принцип законності; принцип судової істини; принцип доступності судового захисту, принцип усності; принцип безпосередності; принцип диспозитивності; принцип змагальності; принцип процесуальної рівноправності сторін.

Отже, у сукупності ці принципи створюють ті засади, на яких будується та функціонує сама процесуальна форма цивільного судочинства і ведеться хід судової справи.

Таким чином, можна зробити висновок, що застосування цих складників веде до відповідних процесуальних дій, які відображаються на результаті розгляду судової справи. Нормативне, законне використання судом, учасниками цивільного процесу стадійного руху справи, правильного оформлення процесуальних актів-документів, застосування послідовності демократичних принципів цивільного судочинства веде до законного, обгрунтованого, якісного вирішення цивільної справи. Процесуальна форма натепер у цивільному законодавстві має всі умови для скорішого розгляду і вирішення цивільної справи. Процесуальна форма, зміст цивільного судочинства не мають розходитись з нормами ЦПК України, що своєю чергою забезпечує суд, що являє собою певну гарантію у разі винесення законного й обгрунтованого рішення.

Отже, це дає змогу зафіксувати поняття «процесуальна форма», що являє собою складну стадійну структуру (конструкцію), підкріплену певними правовими категоріями, без яких не може здійснюватися судом і учасниками цивільного процесу рух цивільної справи. Процесуальна форма є правовою формою державної діяльності, специфічним їі різновидом.

Таким чином, дотримання процесуальної форми у судовій діяльності є суттєвою гарантією встановлення істини, важливою гарантією законності процесуального діловодства $з$ цивільних справ, гарантією забезпечення прав і законних інтересів громадян, які беруть участь у справі, гарантією законності й обгрунтованості всіх рішень (ухвал), які приймаються судом. 
Ефективність вирішення цивільної справи, законність та обгрунтованість винесеного судового рішення у майбутньому залежить перш за все від певної юридичної техніки, документування як основних механізмів діловодства роботи суду, що охоплюють всі аспекти судової діяльності, згідно зі стадійним рухом цивільної справи.

Отже, юридична техніка - це система методів і засобів, професійних юридичних правил і процедур, які використовуються для забезпечення письмової побудови, конструктивності та досконалості правових актів.

Для кожної стадії цивільного процесу складаються групи норм, які регулюють дії суду, і відносини між ними, які утворюються у результаті цих дій. Послідовність стадій, дій, застосування різних норм процесуального права і виникнення процесуальних відносин суворо зумовлена. Так, спочатку має наступити стадія відкриття провадження у справі, яка збігається з пред'явленням позову та прийняттям судом позовної заяви. Після неї наступає стадія провадження у справі до судового розгляду і т. ін. Стадії не можуть рухатись без цього порядку, а відповідно, не може бути іншої послідовності дій.

Отже, абсолютно очевидним є те, що кожна стадія цивільного процесу напряму залежить від тієї процесуальної послідовності та юридичної техніки викладення процесуальних дій у цивільній справі.

Актуальним залишається питання стосовно взаємозв'язку стадій цивільного судочинства (процесуальної форми) 3 юридичною технікою викладення процесуального матеріалу, адже нема єдиної думки щодо взаємозв'язку цих двох елементів, бо юридична техніка розглядається вченими і як процес документування судом, і як певні прийоми, які використовуються у суді.

Так, А.В. Корж розглядає сам процес документування і вказує на те, що вимоги до самого документа можна кваліфікувати за правовими, мовними, логічними і технічними ознаками. А саме правові вимоги виявляються в тому, що документ видає повноважений орган чи особа відповідно до їх компетенції; він має відповідати чинному законодавству і директивним вказівкам керівних органів; має бути достовірним і відповідати завданням конкретного керівництва, тобто базуватися на фактах і містити конкретні пропозиції або вказівки; має відповідати своєму призначенню і укладатися за встановленою формою; бути бездоганно відредагованим та оформленим ${ }^{15}$.

15 Корж А.В. Документація праводілової форми : навчальний посібник: лекції та зразки документів. Ін-т держави і права ім. В.М. Корецького НАН. Нац. акад. внутрішніх справ України: Київ, 2002. С. 21. 
А от на думку Є.С. Шуриної, є таке поняття, як «об'єкт юридичної техніки», який являє собою текст юридичного документа, у відношенні з яким пристосовуються інтелектуальні зусилля нормотворця. Саме останній і реалізує різні правила і прийоми підготовки юридичних документів. Автор вказує на те, що юридична техніка являє собою «ділові звичаї», тобто дії і прийоми, які склалися у ході правотворчої діяльності. Вони мають бути закріплені у спеціальних нормативних актах. Правила підготовки текстів юридичних документів різноманітні i багатогранні. Юридична техніка має відповідати таким основним вимогам, як: регулювання належної сфери відносин у досить повному обсязі; конкретність регулювання; неприпустимість декларативності; логічне викладення матеріалу, зв'язок нормативних розпоряджень між собою; точне використання юридичних конструкцій; виправдане використання тих чи інших засобів викладення елементів правових норм; недоцільне повторення положень у нормативно-правових актах органів влади вищого рівня; точність визначення застосованої юридичної форми; формулювань, виразів, окремих термінів; ясність і доступність мови адресата у викладенні документів; використання апробованих усталених термінів і виразів, які мають широке використання; максимальна економічність, оптимальна ємність, компактність формувань; системність побудови документів: цільність, збалансованість, внутрішній зв'язок і взаємозв'язок усіх частин, логічна послідовність викладення; уніфікація, одноманітність форми і структури юридичного документа, засобів викладення правових умов ${ }^{16}$.

Г.П. Проценко та Л.П. Шестопалова у своїй праці приділяють більше уваги лінгвістиці, мовному вираженню, вони вважають, що юридична лінгвістика виникає на стику лінгвістики і права, ще перебуває на стадії свого оформлення. Актуальними завданнями юридичної лінгвістики $\epsilon$ вивчення і розроблення мови у сфері законодавства та судочинства; дослідження юридичної аргументації; розроблення стародавніх правових текстів; визначення мовних норм у праві, оформлення системи юридичної термінології; вироблення критеріїв трактування текстів; напрацювання мовних вимог до юридичних формулювань; електронні юридичні словники; співвідношення лінгвістичної експертизи і правничої лінгвістики; аналіз якості мови і стилю законодавства тощо ${ }^{17}$.

\footnotetext{
16 Шурина Е.С. Техника юридического письма : учебно-практическое пособие. Американская ассоциация юристов. Программа АВАСЕЕЛИ; акад. нар. хоз-ва при правительстве Рос. Федерации. Москва : Дело, 2000. С. 25.

17 Правнича лінгвістика: навчальний посібник / Г.П. Проценко, Л.М. Шестопалова, О.Ф. Прохоренко та ін. ; за заг. ред. С.М. Гусарова. Київ : ПАЛИВОДА А.В., 2010. С. 8; 20-21. 
Отже, все зазначене дає змогу зробити висновок, що цивілістика взагалі не розглядає питання юридичної техніки, хоча у повному обсязі досить використовує певні елементи юридичної техніки, поняття «документування», викладення процесуального матеріалу судом у цивільній справі. Безперечно, є певна різниця між правоутворенням норми права законодавчим органом і використанням та утворенням процесуальних актів-документів судом, адже суд залежить від норм ЦПК України та від ходу та розгляду специфічних цивільних справ.

Не слід забувати про сам суд, який є практично одним місцем, де послідовність мови має суворо зумовлений порядок. Співвідношення письмової та усної форми вираження учасниками судового процесу є дуже важливим фактором збору інформації, доказів для суду.

Так, на думку Р.В. Тертишнікова, судове пізнання має проходити у рамках процесуальної форми, тобто встановленого процесуальними нормами порядку визначення кола фактів, які підлягають встановленню, та доказів, що можуть їх підтверджувати чи спростувати, порядок надання та витребування зазначених доказів, їх оцінка та дослідження ${ }^{18}$.

Отже, доказування (докази) на різних стадіях судового процесу, якщо воно (вони) використовуються судом, являють певну юридичну цінність і автоматично стають процесуальними, тобто тими, які будуть впливати і впливають на законне й обгрунтоване рішення з цивільної справи.

Не слід також забувати про такий сучасний важливий аспект, як фіксація цивільного судочинства. Це певний процесуальний порядок збору інформації, фіксації та документального оформлення, на цій основі суд встановлює наявність чи відсутність значимих фактів для ухвалення законного та обгрунтованого судового рішення.

Отже, $є$ необхідність зазначити у цивілістиці такий термін, як «юридична техніка», визначити іiі вплив на стадії судового процесу, а також на процесуальну форму цивільного процесу загалом, охарактеризувати іiі згідно з використанням цивільним судом та учасниками судового процесу. 3'ясувати, наскільки взаємозалежними одне від одного $\epsilon$ поняття усного викладення інформації, іiі документального оформлення та фіксації судового процесу загалом.

Перш за все слід зазначити, що правильне застосування прийомів юридичної техніки засноване на єдності форми і змісту процесуального

18 Цивільний процесуальний кодекс України: станом на 2 лютого 2018 року. Харків : Право, 2018. С. 13. 
цивільного судочинства, його «духу» (норми права) i «літери» (процесуальні акти-документи, які використовуються у суді).

Вважаємо, що термін «юридична техніка» цивільного судочинства охоплює цілу ланку елементів, без яких вона не може існувати. Ведення, оформлення, розгляд, вирішення судової справи перш за все залежить від суду (судді), який планує розгляд конкретної справи. Планування роботи в судах, на відміну від інших органів державної влади, має свою специфіку, яка пов'язана із процесуальним статусом цього органу. Суддя, приймаючи цивільну справу до розгляду, має на майбутнє спланувати ії можливий хід та використання певних нормативних актів цивільного процесу, іiї оформлення та фіксацію. Це і буде відображати процесуальну форму і зміст цього судового розгляду.

Суд $є$ тим органом, який має забезпечити точний хід судового процесу, належне оформлення, зберігання, обгрунтування, правомірну видачу, законну силу юридичного документа. Це неодмінні умови, які забезпечують законність і правопорядок у суспільстві, стабільність і захист громадських інтересів і прав громадян, нарешті, продуктивну діяльність органів держави.

Актуальним залишається вдосконалення письмової процесуальної форми документів, іiі вимог, які є необхідним матеріалом, що широко використовується як в юридичній науці, так і в практиці. Вимогам процесуального документа у цивільному процесі приділяється особлива увага. Це певна система вимог, які створюють безпосередній зміст процесуальної форми, стадійності руху цивільної справи, форми і фіксації доказування і тому знаходять своє офіційне нормативне закріплення. Причому слід вказати, що завданням аналізу всісї різноманітності процесуальних актів-документів з цивільних справ є об' єктивна оцінка з метою вдосконалення і конструктивної зміни форми і змісту кожного процесуального акта-документа за своїм функціональним призначенням.

Таким чином, щоб забезпечити стабільність процесуального оформлення юридичних документів, необхідна належна юридична техніка викладення кожного з них, яка дає значення про конкретні умови оформлення юридичного документа та фіксації судового процесу, ведення судової справи загалом, а також можливо припустити, що вдале вирішення справи залежить від кваліфікації суду (судді), який застосовує певні прийоми і способи юридичної техніки. I це можливо розглядати як виникнення певної процесуальної форми і змісту самої цивільної судової справи. 
Тобто характер і особливості процесуальної форми визначаються тим змістом, який втілений у цю форму. Процесуальна форма і зміст є формою судової діяльності і відносин, які виникають із цієї діяльності, оскільки іії особливості визначаються змістом викладення юридичного матеріалу розгляду справи за допомогою юридичної техніки ведення судового процесу, змістом діяльності суду.

\section{ВИСНОВКИ}

Усе вищезазначене дає змогу зробити висновок, що без такої категорії, як «юридична техніка», неможливо вести цілеспрямований, правильний, законний і обгрунтований процес. Для цивільного розгляду справи «юридична техніка» має значення у трьох аспектах: документальне оформлення, фіксація судового процесу та усний розгляд справи, що, безперечно, сприяє викладенню певної інформації для учасників судового процесу та його вирішення.

Процесуальна форма та зміст цивільного процесу не можуть існувати без юридичної техніки, оскільки здійснення правосуддя базується на діяльності суду та учасників цивільного процесу, ця діяльність має суворо дотримуватися норм процесуального права, тобто бути певними санкціонованими законом правилами, притаманними для здійснення правосуддя.

Таким чином, з огляду на зазначене, можна сформулювати поняття «юридична техніка для ичивільного процесу» - це специфічний, процесуальний, фіксований засіб вираження стадійного руху цивільної справи, який характеризується лінгвістичними, технічними способами і прийомами застосування і використанням викладення інформації учасниками судової справи.

Маємо запропонувати такі ознаки юридичної техніки для изивільного процесу, а саме: 1) юридична техніка ведення судової справи не може існувати без застосування норм права; 2) ведення судової справи судом залежить від юридичної техніки, яка притаманна саме певній стадії судового процесу; 3) юридична техніка ведення судової справи залежить від компетенції та підготовки суду; 4) юридична техніка характеризується документообігом суду, фіксацією судового процесу та усною формою викладення інформації учасниками судового процесу; 5) на основі юридичної техніки, яка застосовується учасниками судового процесу, формується процесуальна форма і зміст судового процесу; 6) процесуальний акт-документ залежить не тільки від норми цивільного процесуального права, але і від точного застосування юри- 
дичної техніки в оформленні цих документів; 7) юридична техніка оформлення, фіксації судового процесу впливає на винесення законного й обгрунтованого рішення у справі.

Отже, юридична техніка - це набагато більша категорія для цивілістики, а також для цивільного процесу загалом. Вона має значення для цивільної процесуальної структури у вигляді певних заходів, які передбачені законом, лінгвістичними нормами викладення документа, які гарантуються судом як специфічним учасником судового процесу.

\section{АНОТАЦІЯ}

У цій науковій праці був проведений аналіз складу процесуальної форми цивільного судочинства. Визначено поняття «процесуальна форма», а саме вона являе складну стадійну структуру (конструкцію), підкріплену певними правовими категоріями, без яких не може здійснюватися судом і учасниками цивільного процесу. Процесуальна форма цілком залежить від наповненості ії змісту та певних елементів, без яких неможливо представити сам цивільний процес. Процесуальна форма являє собою певну частину процесуальних правил, встановлених процесуальним законодавством. Правила, які не встановлені законом, не можуть регулювати порядок діяльності осіб, які беруть участь у справі. Доведено, що процесуальна форма цивільного процесу являє собою сукупність певних правил, які визначають зміст поведінки суду і учасників процесу, порядок та послідовність такої поведінки здійснюється у рамках цивільних процесуальних правовідносин; визначення місця і строків реалізації процесуальних прав та обов'язків; визначення доказової бази; визначення логічності та послідовності процесуальних дій; фіксацію процесуальних дій та руху цивільного процесу. Зазначено, що суд є спеціальним, виключним учасником цивільного процесу, який має регулювати дотримання процесуальних норм цивільного судочинства, є гарантом реалізації процесуальної форми цивільного законодавства та винесення законного та обгрунтованого судового рішення. Кожна стадія характеризується своїм специфічним змістом, колом суб'єктів процесуальної діяльності, особливим процесуальним оформленням.

Процесуальна форма є правовою формою державної діяльності, специфічним їі різновидом. 


\section{ЛІТЕРАТУРА}

1. Цивільний процесуальний кодекс України: станом на 2 лютого 2018 року. Харків : Право, 2018. 264 с.

2. Тертишніков Р.В. Доказування і докази в судочинстві України : науково-практичний посібник. Харків : Видавництво «ФІНН», 2009. 88 с.

3. Горшенёв В.М. Способы и организационные формы правового регулирования в социалистическом обществе. Москва: Юрид. лит., 1972. $256 \mathrm{c.}$

4. Юридическая процессуальная форма: теория и практика / Под общ. ред. Гл.-кор. АН КССР Недбайло П.Е. и д-ра юрид. наук Поршнева В.М. Москва : Юрид. лит., 1976. 280 с.

5. Шпилев В.Н. Содержание и форма уголовного судопроизводства. Минск : Изд-во БГУ, 1974. 143 с.

6. Якуб М.А. Процессуальная форма в советском уголовном судопроизводстве. Москва : Юрид. лит., 1981. 144 с.

7. Організація роботи суду: навчальний посібник для студентів юридичних спеціальностей вищих навчальних закладів. / I.Є. Марочкін, Л.М. Москвич, О.М. Овчаренко та ін. ; за заг. ред. І.Є. Марочкіна. Харків : Право, 2012. 256 с.

8. Кушнаренко Н.Н. Документоведение : учебник. 8-е изд., стер. Киев : Знання, 2008. 459 с.

9. Олійник О.Б. Судова документація : навчальний посібник. Київ: Алерта, 2007. 282 с.

10. Васильєв С.В. Цивільний процес : навчальний посібник. Харків : Еспада, 2014. 416 с.

11. Барікова А.А. Електронна держава: нова ефективність урядування : монографія. Київ : Юрінком Інтер, 2016. 224 с.

12. Кушакова-Костицька Н.В. Електронне правосуддя: українські реалії та зарубіжний досвід. Юридичний часопис Національної академії внутрішніх справ. 2013. № 2(4). С. 5-15.

13. Онищук I.I. Техніка юридичного письма в нормативно-правових актах : монографія. Івано-Франківськ: Лабораторія академічних досліджень правового регулювання та юридичної техніки, 2014. 228 с.

14. Юридична аргументація. Логічні дослідження : монографія / О.М. Юркевич, В.Д. Титов, С.В. Куцепал та ін. ; за заг. ред. О.М. Юркевич. 2-ге вид, переробл. та допов. Харків : Право, 2015. 336 с.

15. Корж А.В. Документація праводілової форми : навчальний посібник: лекції та зразки документів. Ін-т держави і права ім. В.М. Корецького НАН. Нац. акад. внутрішніх справ України. Київ, 2002. 231 с.

16. Шурина Е.С. Техника юридического письма : учебно-практическое пособие. Американская ассоциация юристов. Программа АВАСЕЕЛИ; 
акад. нар. хоз-ва при правительстве Рос. Федерации. Москва: Дело, $2000.271 \mathrm{c}$.

17. Правнича лінгвістика : навчальний посібник / Г.П. Проценко, Л.М. Шестопалова, О.Ф. Прохоренко та ін. ; за заг. ред. С.М. Гусарова. Київ : ПАЛИВОДА А.В., 2010. 312 с.

18. Цивільний процесуальний кодекс України: станом на 2 лютого 2018 року. Харків : Право, 2018. 264 с.

\section{Information about the authors:} Perunova O. M., PhD. in Law Science, Associate Professor, Associate Professor of Accounting, Taxation and International Economic Relations Kharkiv National Automobil Highway University 25, Yaroslava Mudrogo str., Kharkiv, Ukraine Leontieva L. V.,

PhD. in Law Science, Associate Professor, Associate Professor of Accounting, Taxation and International Economic Relations Kharkiv National Automobil Highway University 25, Yaroslava Mudrogo str., Kharkiv, Ukraine

DOI https://doi.org/10.30525/978-9934-588-43-3/2.16 